\title{
Isolation of Mature Adipocytes and Stromal Vascular Cells under Adverse Sampling Conditions

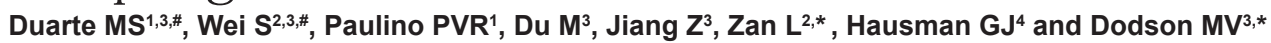

${ }^{1}$ Department of Animal Sciences, Universidade Federal de Viçosa, Viçosa, MG 36570-000, Brazil

${ }^{2}$ College of Animal Science and Technology, Northwest A\&F University, Yangling, Shaanxi Province 712100, China

${ }^{3}$ Department of Animal Sciences, Washington State University, Pullman, WA 99164, USA

${ }^{4}$ USDA, ARS, Athens, GA 30605, USA

"contributed equally to this effort

\begin{abstract}
Methods are described to obtain adipose tissue for cell isolation, under adverse isolation conditions whereby no scientific controls were in place. Such methods could be used by laboratories of institutions where controlled environments (surgery rooms, abattoirs) are not available. While not ideal, we show that a variety of adipocytes and adipocyte-like cells may be isolated from such methods. These types of procedures may facilitate a greater number of persons entering into the research arena with adipocytes, and are easily adaptable to other animal models.
\end{abstract}

Keywords: Beef; Custom pack; Adipose tissue; Stromal vascular cells; Mature adipocytes; Isolation; Limited facilities; Adipocyte; Cell culture; Mature adipocytes; Stromal vascular

\section{Introduction}

Adipocytes are cells that comprise a portion of any adipose depot. While they are not the only cells present in the adipose depot [1], discernible adipocytes function to assimilate moderate and long-chain fatty acids, store them as triacylglycerol, and release the fatty acids in times of negative energy balance, or in response to a repartitioning agent $[1,2]$. Adipocytes of some adipose depots also synthesize and release regulatory cytokines into the blood, which have been postulated to regulate a variety of whole animal and local non-adipose tissue physiology $[1,3,4]$. As such, in addition to moderating aspects of energy balance, adipocytes also may play a role in altering the body's blood pressure $[3,4]$, ability to respond to insulin, control the rate of cellular apoptosis, fight inflammation and maintain normal levels of connective tissue surrounding tissues [5,6]. Adipocytes have been directly linked to obesity, metabolic syndrome, hypertrophy of the heart, and numerous other dynamic pathologies [7-9].

Stromal Vascular (SV) cells in adipose depots are present and active in the presence of fully differentiated adipocytes [10], and rodentderived cells have largely been used as a model for defining aspects of adipogenesis [1]. Are there other animal models that may help in defining aspects of adipocyte physiology, whereby adipocytes from all adipose depots are abundantly available? Research with large animals (such as cattle) provides such an animal model. These types of animals form the foundation of the National Institute of Health/United States Department of Agriculture directive towards use of "dual purpose animals" for both human and animal production-related research, because these large animals are good models/donors for studying molecular/cellular mechanisms of adipocyte physiology. For example, cattle are sufficiently large that all adipose depots may be easily sampled at the same time for comparative adipogenesis studies (depot vs depot), or individually (intramuscular depot) for adipogenesis and lipid metabolism studies $[11,12]$. In addition, the expanding marker databases of cattle promote the usage of this model.

Previous research with beef-derived adipocyte isolation utilized existing animal facilities in controlled environments such as either a local surgical suite or a meat laboratory (abattoir). This allows one to be capable of controlling the environment to which tissues are initially prepped/isolated/handled and packaged for transport. Moreover, tissue obtained for cell isolation could be extracted from the donor animal fast, efficiently transferred to a sterile (buffer) environment, and (all) promptly returned to the cell culture laboratory for processing. What about those without such facilities such as urban medical schools, researchers at (very) small colleges or other countries whereby facilities are quite limited? Can tissues be isolated from beef cattle if none of the environmentally controlled facilities are available? The focus of this paper was to obtain skeletal muscle from beef animals, which were being terminated and initially processed by a custom-packing/ processing company with on-the-farm service. If successful, such tissue procurement results may immediately suggest that research personnel with few facilities might be in a position to conduct research in this area.

\section{Material and Methods}

\section{Animals and pre-slaughter material preparation}

Animals used for tissue sampling were slaughtered in a beef farm located in Viola, Idaho-USA by using a mobile slaughter unit (Figure 1). No attempt was made to influence their normal procedures. Instead, representatives of the commercial entity physically provided samples to laboratory personnel. Immediately after receipt of the samples, laboratory individuals returned to the cell culture laboratory expediently. However, the locale and personnel responsible for handling of the live animals/slaughter of the same/obtaining the muscle samples, and providing the samples to the laboratory personnel was new and never used for any work like this previously. Thus, we were not able to control any of the steps in tissue isolation-other than to request the specific muscle that should be sampled. Cattle were simultaneously slaughtered by cerebral concussion followed by jugular venesection

*Corresponding authors: Dodson MV, Department of Animal Sciences, Washington State University, Pullman, WA 99164, USA, E-mail: dodson@wsu.edu Zan L, College of Animal Science and Technology, Northwest A\&F University, Yangling, Shaanxi Province 712100, China, E-mail: zanls@yahoo.com.cn

Received July 09, 2012; Accepted August 12, 2012; Published August 16, 2012

Citation: Duarte MS, Wei S, Paulino PVR, Du M, Jiang Z, et al. (2012) Isolation of Mature Adipocytes and Stromal Vascular Cells under Adverse Sampling Conditions. J Metabolic Synd 1:112. doi:10.4172/2167-0943.1000112

Copyright: (c) 2012 Duarte MS, et al. This is an open-access article distributed under the terms of the Creative Commons Attribution License, which permits unrestricted use, distribution, and reproduction in any medium, provided the original author and source are credited. 


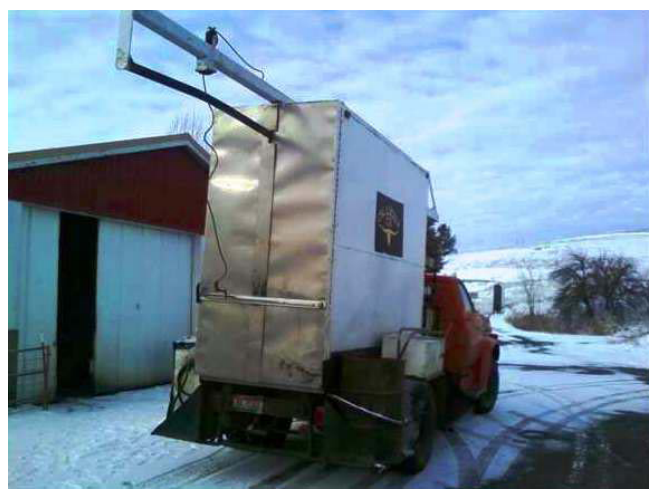

Figure 1: Mobile unit used for cattle slaughter and transit to processing facilities. The picture also shows the cold weather conditions of the day that the samples were collected. The snow on the ground contributed for a muddy yard where the cattle were harvested and the muscle samples were collected.

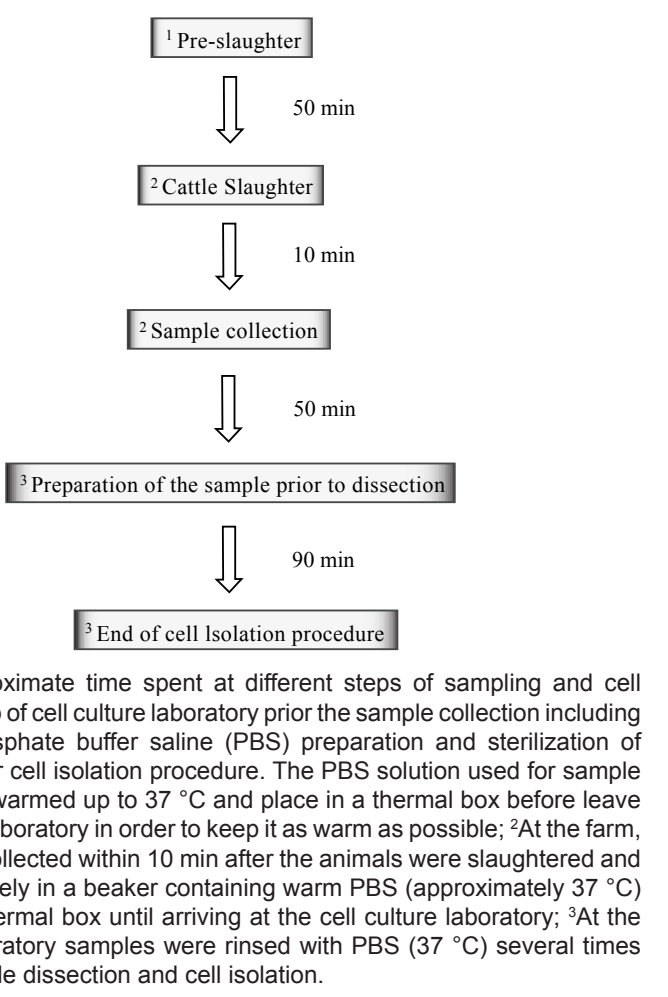

and the muscle samples were collectively collected immediately after bleeding.

The cell culture laboratory was prepared for cell isolation procedure one day before the tissue sampling. All the supplies needed including plastic and glassware, and buffer solution (PBS) were sterilized prior the tissue collection in order to optimize the cell isolation procedure. The buffer solution was warmed in a water bath to $37^{\circ} \mathrm{C}$ and kept in a thermal box during the pre-slaughter until the samples collection in order to keep it as warm as possible.

\section{Tissue samples}

At the farm, samples of sternomandibularis muscle from four Angus cattle were collected within $10 \mathrm{~min}$ after slaughter and immediately placed in a sterile beaker containing warm phosphate buffered saline (PBS) supplemented with $100 \mathrm{IU} / \mathrm{ml}$ penicillin, $100 \mu \mathrm{g} /$ $\mathrm{ml}$ streptomycin, $2.5 \mathrm{ng} / \mathrm{ml}$ Fungizone B and $50 \mu \mathrm{g} / \mathrm{ml}$ Gentamicin. The beakers containing the tissue were placed in a thermal box as soon as the samples were collected in order to keep the samples warm, and then taken to the cell culture laboratory. As soon as the samples arrived at the cell culture laboratory they were immediately processed $50 \mathrm{~min}$ after collection and delays were avoided on the way back to the cell culture laboratory in order to short the time between sampling and cell isolation. A timeline of the sample collection and cell isolation procedure is presented in Figure 2.

\section{Cell isolation procedure}

Mature Adipocytes (MAs) and Stromal Vascular (SV) cells from Intramuscular Fat (IMF) depot were isolated as described by Fernyhough et al. [13] with minor modifications as it follows (Figure 3). Preparation of reagents and media used for cell isolation is described in Table 1.

1. Rinse the muscle sample with $\mathrm{PBS}\left(37^{\circ} \mathrm{C}, \mathrm{pH}=7.08\right)$ supplemented with antibiotics/antimycotics and trim it prior to muscle dissection in order to reduce chances of contamination.

2. In a laminar flow hood, place the sample in a sterile dish, bath in PBS. Using sterile forceps and scissor dissect the muscle tissue in order to access the intramuscular fat depots. Once beginning the sample dissection, do not turn the tissue upside down since to keep the interior of the sample as clean as possible.

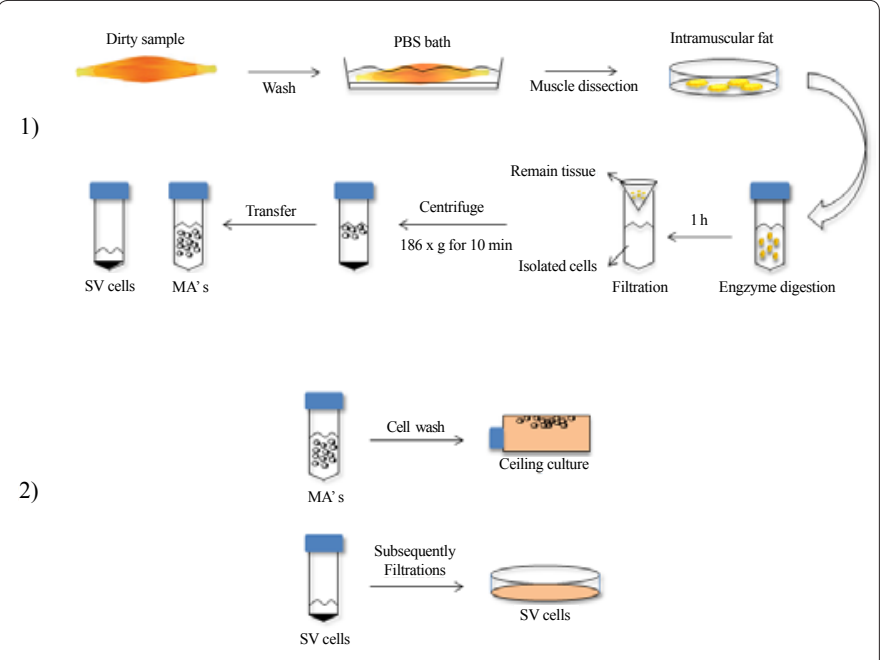

Figure 3: Flow diagram with the steps of the cell isolation procedure within the cell culture laboratory: 1) Preparation of muscle sample, muscle dissection and mature adipocytes (MA's) and stromal vascular (SV) cells isolation - muscle samples were rinsed several times with PBS containing antibiotics and antimycotics in order to clean the samples as much as possible before taking it to the lamina flow hood. Once washed, samples were bath in sterile PBS placed in a dish inside of the lamina flow hood for muscle dissection. Fragments of intramuscular fat $(5 \mathrm{~g})$ was isolated from the muscle using sterile forceps and placed in a $10 \mathrm{~cm}$ dish containing PBS and minced into small pieces in order to increase the surface area to optimize the enzyme digestion. Minced tissue was digested by collagenase type I for $1 \mathrm{~h}$ at $37{ }^{\circ} \mathrm{C}$. After digestion, the solution was filtered through $1000 \mu \mathrm{m}$ plastic mesh to separate the digested tissue from the cells. The solution containing isolated cells was centrifuged at $186 \times g$ for $10 \mathrm{~min}$ and the two types of cells were segregated. MA's were found at the top layer of the solution and SV cells were found at the pellet on the bottom of the tube 2) MA's were transferred into a new tube and washed by centrifugation at $186 \mathrm{xg}$ twice with DMEM/F12 + 10\% FBS before plating in a $12.5 \mathrm{~cm}^{2}$ flask completely filled with DMEM/F12 + 10\% HS. The SV cells were resuspended with DMEM/F12 $+10 \%$ FBS and filtered subsequently through a $100 \mu \mathrm{m}$ and $40 \mu \mathrm{m}$ mesh filter before plating with the same media in a $10 \mathrm{~cm}$ dish. 
Citation: Duarte MS, Wei S, Paulino PVR, Du M, Jiang Z, et al. (2012) Isolation of Mature Adipocytes and Stromal Vascular Cells under Adverse Sampling Conditions. J Metabolic Synd 1:112. doi:10.4172/2167-0943.1000112

Page 3 of 4

\begin{tabular}{|c|c|c|c|}
\hline Solution & Chemical & Amount & Comments \\
\hline \multicolumn{4}{|l|}{ PBS $(\mathrm{pH}=7.08)$} \\
\hline & $\mathrm{NaCl}$ & $10.0 \mathrm{~g}$ & \multirow{4}{*}{$\begin{array}{l}\text { PBS must be autoclaved at } \\
121^{\circ} \mathrm{C} \text { at } 15 \text { psi for } 30 \text { min } \\
\text { in a glass bottle. Before the } \\
\text { addition of antibiotics and } \\
\text { antimycotics the solution } \\
\text { must be cooled. After } \\
\text { add the antibiotics and } \\
\text { antimycotic the solution } \\
\text { must be store at } 4^{\circ} \mathrm{C} \text {. }\end{array}$} \\
\hline & $\mathrm{KCl}$ & $0.25 \mathrm{~g}$ & \\
\hline & $\mathrm{Na}_{2} \mathrm{HPO}_{4}$ & $1.44 \mathrm{~g}$ & \\
\hline & Distilled $\mathrm{H}_{2} \mathrm{O}$ & $\begin{array}{l}1 \mathrm{I} \\
\text { (final volume) }\end{array}$ & \\
\hline \multirow[t]{4}{*}{$\begin{array}{l}\text { DMEM/F12 (pH = } \\
7.08)\end{array}$} & & & \multirow{4}{*}{$\begin{array}{l}\text { The solution must be filter } \\
\text { sterilized in the lamina flow } \\
\text { hood passing the media } \\
\text { through a } 0.22 \mu \mathrm{m} \text { pore filter } \\
\text { into a sterile } 1-\mathrm{l} \text { bottle. Store } \\
\text { at } 4^{\circ} \mathrm{C} \text {. }\end{array}$} \\
\hline & DMEM/F12 mixture & 1-I envelope & \\
\hline & $\mathrm{NaHCO}_{3}$ & $2.438 \mathrm{~g}$ & \\
\hline & Distilled $\mathrm{H}_{2} \mathrm{O}$ & $\begin{array}{l}1 \mathrm{I} \\
\text { (final volume) }\end{array}$ & \\
\hline \multirow[t]{3}{*}{ Enzyme solution } & & & \multirow{3}{*}{$\begin{array}{l}\text { Collagenase must be } \\
\text { dissolve in } 100 \mathrm{ml} \text { of PBS } \\
\left(37^{\circ} \mathrm{C}\right) \text { and subsequently } \\
\text { filter sterilized by passing } \\
\text { the solution through a } 0.22 \\
\mu \mathrm{m} \text { pore vacuum filter. The } \\
\text { solution must be prepared } \\
\text { just before use. }\end{array}$} \\
\hline & Collagenase type I & $0.25 \mathrm{~g}$ & \\
\hline & PBS & $100 \mathrm{ml}$ & \\
\hline \multirow[t]{5}{*}{$\begin{array}{l}\text { DMEM/F12 + 10\% } \\
\text { serum } \\
\text { (FBS or HS) }\end{array}$} & & & \multirow{5}{*}{$\begin{array}{l}\text { Basal medium must be } \\
\text { prepared in a lamina flow } \\
\text { hood by adding serum } \\
\text { and antibiotics to the final } \\
\text { volume of } 500 \mathrm{ml} \text {. Store at } \\
4^{\circ} \mathrm{C} \text {. }\end{array}$} \\
\hline & $\begin{array}{l}\text { DMEM/F12 } \\
\text { solution }\end{array}$ & $442.5 \mathrm{ml}$ & \\
\hline & Serum (FBS or HS) & $50 \mathrm{ml}$ & \\
\hline & $\begin{array}{l}\text { Penicillin/ } \\
\text { streptomycin }\end{array}$ & $5.0 \mathrm{ml}$ & \\
\hline & Gentamicin & $2.5 \mathrm{ml}$ & \\
\hline
\end{tabular}

Table 1: Preparation of reagents and media used for cell isolation.

3. Place approximately $5 \mathrm{~g}$ of intramuscular fat tissue in a sterile 10 $\mathrm{mm}$ dish containing $10 \mathrm{ml}$ of PBS. Cut the isolated fat tissue in small pieces (approximately $1-\mathrm{cm}^{2}$ ) and place the minced tissue in a sterile $50 \mathrm{ml}$ centrifuge tube containing $25 \mathrm{ml}$ of warm $\left(37^{\circ} \mathrm{C}\right)$ sterile collagenase type I solution $(0.25 \%$ collagenase in PBS). Place the tube in a rocker and incubate for $1 \mathrm{~h}$ at $37^{\circ} \mathrm{C}$.

4. After the enzyme digestion, filter the solution through a sterile $1000 \mu \mathrm{m}$ plastic mesh in a sterile funnel into a new $50 \mathrm{ml}$ tube.

5. Centrifuge the filtrate for $10 \mathrm{~min}$ at $186 \mathrm{x} \mathrm{g}$. After the centrifugation, an underlying pellet will be seeing at the bottom of the tube which contains the stromal vascular cells and the mature adipocytes will be floating in the top layer of the solution.

6. To isolate the mature adipocytes, gently pipette the top layer of the solution into a new tube. Add the same volume $(1: 1 \mathrm{v} / \mathrm{v})$ of DMEM/F12 + 10\% FBS into the tube and wash the cells twice by centrifugation at $186 \mathrm{x} \mathrm{g}$. After wash the cells, place the isolated mature adipocytes into a $12.5 \mathrm{~cm}^{2}$ cell culture flask filled with DMEM/F12 + 10\% horse serum (HS). Invert the flask so the bottom of the flask is on top and incubate it at $37^{\circ} \mathrm{C}$ in a $5 \% \mathrm{CO}_{2}$ incubator [13].

7. To culture the stromal vascular cells, resuspend the underlying pellet of the digested solution with $10 \mathrm{ml}$ of DMEM/F12 + $10 \%$ FBS and filtered once through a $100 \mu \mathrm{m}$ and subsequently through $40 \mu \mathrm{m}$ cell strainers into a new $50 \mathrm{ml}$ centrifuge tube. After filtration vortex it vigorously and transfer the solution to a $10 \mathrm{~cm}$ dish. Rinse the tube with an additional $10 \mathrm{ml}$ of DMEM/
$\mathrm{F} 12+10 \% \mathrm{FBS}$ and transfer into a cell culture dish. Incubate the isolated stromal vascular cells at $37^{\circ} \mathrm{C}$ in a $5 \% \mathrm{CO}_{2}$ incubator.

\section{Photomicrographs}

All photomicrographs were taken with a Sony RGB digital camera (3/4-inch chip) coupled to a Nikon Diaphot phase contrast microscope and Image Pro Plus image analysis software. The major equipment,

\begin{tabular}{|l|l|c|}
\hline Equipments & \multicolumn{1}{|c|}{ Source } & Model \\
\hline $\begin{array}{l}\text { Autoclave, gravity air } \\
\text { remover type }\end{array}$ & American Sterilizer Company & P-89501-091 \\
\hline $\mathrm{CO}_{2}$ water-jacket incubator & Beckman Instruments Inc. & TJ-6 \\
\hline Dry heat gravity oven & The Newell Group & $1370 \mathrm{GM}$ \\
\hline $\begin{array}{l}\text { Lamina flow, biological safety } \\
\text { cabinet, Labguard Class II }\end{array}$ & Nu Aire Inc. & NU-425-4000 \\
\hline Peristaltic pump & Milipore Corp. & $7015-72$ \\
\hline Pipet aid & Drummond Scientific Co. & 174 \\
\hline pH meter, digital & $\begin{array}{l}\text { Corning Incorporated life } \\
\text { Sciences }\end{array}$ & 430 \\
\hline pH electrode & $\begin{array}{l}\text { Corning Incorporated life } \\
\text { Sciences }\end{array}$ & 47636 \\
\hline Propane torch & Sigma Chemical Company & TS2000 \\
\hline Water bath & Precision Scientific & 185 \\
\hline Microscope & Nikon & $\begin{array}{c}\text { Diaphot-TMD } \\
\text { phase inverted }\end{array}$ \\
\hline
\end{tabular}

Table 2: Major equipment used for cell isolation procedure.

\begin{tabular}{|l|l|c|}
\hline Item & Source & Product Number \\
\hline $\begin{array}{l}\text { Dulbecco's modified eagle's } \\
\text { medium } \\
\text { (DMEM)/Ham's F12 (F12) }\end{array}$ & Invitrogen & $12500-062$ \\
\hline Fetal bovine serum & Invitrogen & $26140-079$ \\
\hline Horse serum & Invitrogen & $16050-114$ \\
\hline Collagenase Type I & Invitrogen & $17100-017$ \\
\hline Gentamicin solution, $10 \mathrm{mg} / \mathrm{ml}$ & Invitrogen & $15710-064$ \\
\hline Penicilin-streptomycin (pen/strep) & Invitrogen & $15140-122$ \\
\hline $\mathrm{KCl}$ & $\begin{array}{l}\text { Sigma Chemical } \\
\text { Company }\end{array}$ & $\mathrm{P}-5405$ \\
\hline $\mathrm{KH}_{2} \mathrm{PO}_{4}$ & $\begin{array}{l}\text { Sigma Chemical } \\
\text { Company }\end{array}$ & $\mathrm{P}-5655$ \\
\hline $\mathrm{NaCl}$ & $\begin{array}{l}\text { Sigma Chemical } \\
\text { Company }\end{array}$ & $\mathrm{S}-5886$ \\
\hline $\mathrm{NaHCO}$ & $\begin{array}{l}\text { Sigma Chemical } \\
\text { company }\end{array}$ & $\mathrm{S}-5761$ \\
\hline
\end{tabular}

Table 3: Media and chemicals used for solutions preparations.

\begin{tabular}{|l|l|c|}
\hline Item & \multicolumn{1}{|c|}{ Source } & Product Number \\
\hline Media bottles & & \\
\hline $125 \mathrm{ml}$ with cap & Wheaton Scientific Products & 219715 \\
\hline $250 \mathrm{ml}$ with cap & Wheaton Scientific Products & 219717 \\
\hline $500 \mathrm{ml}$ with cap & Wheaton Scientific Products & 219719 \\
\hline Pipettes & & \\
\hline $5 \mathrm{ml}$ glass disposable & WWR Scientific Products Corporation & $53283-774$ \\
\hline $10 \mathrm{ml}$ glass disposable & WWR Scientific Products Corporation & $53283-776$ \\
\hline Flask, dishes and centrifuge tube & \\
\hline Tissue culture flask, $25 \mathrm{~cm}{ }^{2}$ & Thermo Fisher Scientific, Inc. & 163371 \\
\hline Tissue culture dish, $10 \mathrm{~cm}$ & Thermo Fisher Scientific, Inc. & 172931 \\
\hline Tissue culture dish, $15 \mathrm{~cm}$ & Thermo Fisher Scientific, Inc. & 168381 \\
\hline $50 \mathrm{ml}$ conical tube, plastic & Thermo Fisher Scientific, Inc. & 339653 \\
\hline
\end{tabular}

Table 4: Glassware and plastic supplies used for cell isolation procedure. 

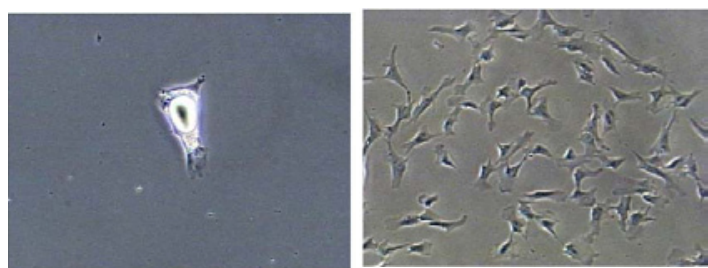

Figure 4: A) $48 \mathrm{~h}$ after cell isolation, mature adipocytes attached the ceiling of flask; B) $7 \mathrm{~d}$ after cell isolation, progeny cells derived from mature adipocytes reached confluence. [A, $200 \times$ magnification; $B, 100 \times$ magnification].
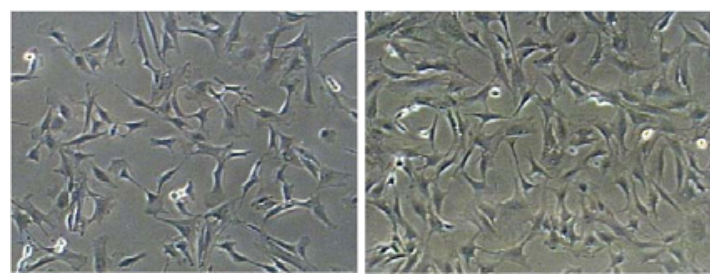

Figure 5: Photomicrographs ( $A$ and $B$ ) of stromal vascular cells cultures $72 \mathrm{~h}$ after cell isolation [100 $\mathrm{x}$ magnification]

media and chemicals, glassware and plastic supplies for cell isolation are presented in Table $2-4$.

\section{Results and Discussion}

It is fairly clear that the environment in which tissue culture is carried out must be clean. This concept leads us to think that for a successful isolation procedure tissue handling must be done with extremely aseptic manner by trained individuals in order to avoid any source of contamination and transported to cell culture laboratory as soon as possible. As such, to isolate cells from a tissue in order to obtain primary cell culture more than an equipped cell culture laboratory is required, being necessary to be as close as possible to the place that the tissues are obtained. Additionally, one of the most important considerations that should be taken prior to cell isolation is the cooperation and collaboration of the clinical staff, which can be easily achieved if a person responsible for tissue isolation is also a member of the cell culture laboratory.

From the moment that a biological sample is removed from its natural environment within the animal, it is susceptible to deterioration from external factors such as moisture loss and temperature fluctuation and excessive passage of time. Another threat to the success of any cell isolation method is contamination from microbial sources including the host's own natural flora. All phases of the isolation process offer opportunities for contamination to occur unless strict adherence to proper aseptic techniques is consistently followed [14]. Additionally, the availability of the cells isolated from a tissue sample also depends on how fast the tissue sampling, dissection and digesting can be done, as in most cases contamination problems are related to the time [15].

In this study Mature Adipocytes (MA; Figure 4) and Stromal Vascular (SV; Figure 5) cells were successfully isolated from bovine muscle collected under non-asepsis conditions. No signs of contamination were detected by microscopy visualization such as cloudiness of media, deterioration of the cells and detachment of the cell monolayer, which would indicate mycoplasm contamination $[16,17]$. The photomicrographs results clearly shows that a great number of cells were successful isolated even though the tissue was collected under adverse conditions and was completely exposed to a non-aseptic environment prior to cell isolation procedures, which was never done in this laboratory before. Additionally, due to the distance between the local of tissue sampling and the cell culture laboratory, the samples were not promptly processed as suggested by several previously studies $[14,18,19]$.

The results obtained in this study encourage new researchers in cell culture field by showing a protocol that allows the isolation of cells from muscle tissue without proper animal facilities. By using the cell isolation procedure developed in our laboratory additionally to the use of basic sterile techniques at the cell culture facility, we were able to obtain non-contaminated, healthy, primary cultures of cells. However, even though we were able to isolate cells in an adverse scenario, it is still recommended the use of sterile techniques during sample collection to avoid contaminations and cell death.

\section{References}

1. Hausman GJ, Dodson MV, Ajuwon K, Azain M, Barnes KM, et al. (2009) Boardinvited review: the biology and regulation of preadipocytes and adipocytes in meat animals. J Anim Sci 87: 1218-1246.

2. Müller G, Petry S (2006) Triacylglycerol storage and mobilization, regulation of. Encyclopedia of Molecular Cell Biology and Molecular Medicine. Aventis Pharma, Germany.

3. Kershaw EE, Flier JS (2004) Adipose tissue as an endocrine organ. J Clin Endocrinol Metab 89: 2548-2556.

4. Dodson MV, Mir PS, Hausman GJ, Guan LL, Du M, et al. (2011) Obesity, metabolic syndrome, and adipocytes. J Lipids 2011: 721686.

5. Li X, Chen R, Lindquist S, Hernell O (2004) Expression of cellular inhibitor of apoptosis protein-2 in human subcutaneous and omental adipose tissue. Int $\mathrm{J}$ Obes Relat Metab Disord 28: 352-356.

6. Keuper M, Blüher M, Schön MR, Möller P, Dzyakanchuk A, et al. (2011) An inflammatory micro-environment promotes human adipocyte apoptosis. Mol Cell Endocrinol 339: 105-113

7. Berg AH, Scherer PE (2005) Adipose tissue, inflammation, and cardiovascular disease. Circ Res 96: 939-949.

8. Poirier P, Giles TD, Bray GA, Hong Y, Stern JS, et al. (2006) Obesity and cardiovascular disease: pathophysiology, evaluation, and effect of weight loss: an update of the 1997 American Heart Association Scientific Statement on Obesity and Heart Disease from the Obesity Committee of the Council on Nutrition, Physical Activity, and Metabolism. Circulation 113: 898-918.

9. Ouchi N, Parker JL, Lugus JJ, Walsh K (2011) Adipokines in inflammation and metabolic disease. Nat Rev Immunol 11: 85-97.

10. Hausman GJ, Dodson MV (2012) Stromal vascular cells and adipogenesis: Cells within adipose depots regulate adipogenesis. Journal of Genomics 1: 56-66.

11. Dodson MV, Hausman GJ, Guan L, Du M, Rasmussen TP, et al. (2010) Lipid metabolism, adipocyte depot physiology and utilization of meat animals as experimental models for metabolic research. Int J Biol Sci 6: 691-699.

12. Dodson MV, Jiang Z, Chen J, Hausman GJ, Guan le L, et al. (2010) Allied industry approaches to alter intramuscular fat content and composition in beef animals. J Food Sci 75: R1-8.

13. Fernyhough ME, Vierck JL, Hausman GJ, Mir PS, Okine EK, et al. (2004) Primary adipocyte culture: adipocyte purification methods may lead to a new understanding of adipose tissue growth and development. Cytotechnology 46: 163-172.

14. Vierck JL, Byrne K, Mir PS, Dodson MV (2000) Ten commandments for preventing contamination of primary cell cultures. Methods Cell Sci 22: 33-41.

15. Reedy SE, Powell DM, Williams NM, Dodson MV, Fitzgerald BP (2000) Thoughts on the source of tissue on subsequent cell culture success. Methods Cell Sci 22: 29-32.

16. Freshney RI (1986) Animal cell culture: a practical approach: Practical approach series. The University of Michigan, Michigan.

17. Freshney RI (1983) Culture of animal cells: a manual of basic technique. (3rd edn), AR Liss, New York.

18. Dodson MV, McFarland DC, Martin EL, Brannon MA (1986) Isolation of satellite cells from ovine skeletal muscles. Methods Cell Sci 10: 233-237.

19. Vierck JL, Dodson MV (2000) Interpretation of cell culture phenomena Methods Cell Sci 22: 79-81. 